\title{
Stimulation of Inositol Trisphosphate and Diacylglycerol Production in Renal Tubular Cells by Parathyroid Hormone
}

Keith A. Hruska, David Moskowitz, Pedro Esbrit, Roberto Civitelli, Scott Westbrook, and Margaret Huskey

Renal Division, Department of Medicine, Jewish Hospital and Washington University, St. Louis, Missouri 63110

\begin{abstract}
Parathyroid hormone (PTH) produced a dose-dependent immediate stimulation of inositol triphosphate and diacylglycerol production in the opossum kidney cell line, primary culture proximal tubular cells, and basolateral membranes from canine proximal tubular segments. The increase in inositol triphosphate production was accompanied by a minor increase in inositol phosphate and no significant increase in inositol bisphosphate production. Associated with the changes in inositol triphosphate and diacylglycerol, there was an immediate hydrolysis of phosphatidylinositol 4'5-bisphosphate. The effect on phospholipid hydrolysis was followed by stimulation of phosphorylation of phosphatidylinositol $4^{\prime}$ monophosphate and phosphatidylinositol. PTH produced a sudden increase in cytoplasmic $\mathrm{Ca}^{2+}$ in oppossum kidney cells that persisted for $\sim 1 \mathrm{~min}$. Inositol triphosphate transiently increased cytoplasmic $\mathrm{Ca}^{2+}$ in saponin-treated opossum kidney and primary culture proximal tubule cells. The effects of PTH were not mimicked by cyclic nucleotides. In fact, cyclic AMP appeared to diminish inositol triphosphate production. These results demonstrate that PTH may activate renal tubular epithelial cells by the production of inositol triphosphate and diacylglycerol.
\end{abstract}

\section{Introduction}

Phosphatidylinositol 4,5-bisphosphate $\left(\operatorname{PtdIns}(4,5)-\mathrm{P}_{2}\right)^{1}$ is a negatively charged phospholipid which, quantitatively, is a minor component of the plasma membrane phospholipid of renal tubular cells. Phosphorylation of PtdIns and PtdIns $(4,5)-P_{2}$ hydrolysis by phospholipase $C$ produces a high membrane turnover rate of PtdIns(4,5)- $\mathrm{P}_{2}$ making it an effective source of second messages for cell activation. In recent years, a variety of hormones and neurotransmitters have been shown to produce cell activation by stimulating phosphodiesteratic hydrolysis of PtdIns(4,5)- $\mathbf{P}_{2}(1,2)$. The products of phospholipase C-stimu-

Address correspondence to Dr. Hruska, Renal Division, Jewish Hospital of St. Louis, 216 S. Kinghighway, St. Louis, MO 63110. 1986

Received for publication 2 June 1986 and in revised form 7 August

1. Abbreviations used in this paper: BLM, basolateral cell membrane; $\left[\mathrm{Ca}^{2+}\right]_{\mathrm{i}}$, cytoplasm calcium; C-kinase, phospholipid-dependent protein kinase; DAG, diacylglycerol; FCCP, (carbonyl) cyanide p-trifluoromethoxyphenylhydrazone; GPI, glycerophosphoinositol; GPIP, GPI phosphate; GPIP $_{2}$, GPI diphosphate; IP, inositol phosphate; $\mathrm{OK}$, opossum kidney; PA, phosphatidic acid; PTC, proximal tubular cells; PtdIns, phosphatidylinositol; PTdIns 4-P, PtdIns 4'-monophosphate; PtdIns(4,5)$\mathrm{P}_{2}$, PtdIns 4,5-biphosphate; TBAS, tetrabutylammonium sulfate.

J. Clin. Invest.

(a) The American Society for Clinical Investigation, Inc.

0021-9738/87/01/0230/10 \$1.00

Volume 79, January 1987, 230-239 lated hydrolysis, diacylglycerol (DAG), and inositol 1,4,5-triphosphate $\left(\mathrm{IP}_{3}\right)^{2}$, are messages which in turn activate phospholipid-dependent protein kinases (C-kinase) and produce transient rises in cytoplasmic calcium $\left(\left[\mathrm{Ca}^{2+}\right]_{\mathrm{i}}\right)$. Thus, DAG and $\mathrm{IP}_{3}$ control two branches of the calcium messenger system, the C-kinase branch and the calmodulin branch (4). The action of $\mathrm{IP}_{3}$ to increase $\left[\mathrm{Ca}^{2+}\right]_{i}$ results from calcium release from the endoplasmic reticulum (5-7). However, there are additional mechanisms of cell signalling through $\mathrm{Ca}^{2+}$, because several hormones increase calcium entry from the extracellular space to produce their biologic effect $(4,8-11)$. The increase in $\left[\mathrm{Ca}^{2+}\right]_{\mathrm{i}}$ produced by agonist stimulated $\mathrm{IP}_{3}$ production or influx across the plasma membrane activates cellular secretion, contraction, and several other functions $(1,2,12)$. Many of the functions stimulated by the rise in $\left[\mathrm{Ca}^{2+}\right]_{i}$ are mediated by calmodulin or other intracellular $\mathrm{Ca}^{2+}$ receptor proteins, thus its designation as the calmodulin branch of the $\mathrm{Ca}^{2+}$ messenger system (4).

Cell activation by parathyroid hormone (PTH) remains enigmatic. Most reports $(13,14)$ suggest that PTH binds to a single class of noninteractive receptors, although Scatchard analysis of the binding of ${ }^{125}$ I-labeled (Nle8, Nle18, Tyr34) b-PTH 1-34 revealed possible heterogeneity of receptors (15). PTH-receptor complexes clearly stimulate cell function through coupling to adenylate cyclase (16). However, recent studies have demonstrated that PTH increases $\left[\mathrm{Ca}^{2+}\right]_{i}$ in proximal tubular cells (PTC) of the mammalian kidney (17) independent of cyclic nucleotides. This indicates that the PTH-receptor complex also couples to a mechanism producing a $\mathrm{Ca}^{2+}$ transient. One such mechanism would be receptor-mediated $\operatorname{PtdIns}(4,5)-\mathrm{P}_{2}$ hydrolysis and Ins $(1,4,5)-\mathrm{P}_{3}$ production. Several investigators $(18-21)$ have shown an effect of PTH on renal tubular phosphoinositide metabolism, and one report shows the effect was present in the apical membrane of the proximal renal tubule (18). Some have reported that the stimulation of phosphoinositide metabolism by PTH was cyclic AMP dependent (19). This would remove it from a mechanism of cell activation, and place it in the realm of a biologic response. However, other investigators $(20,21)$ have not found a stimulation of phosphoinositide metabolism by cyclic AMP in the renal cortex. To date, no report has demonstrated production of the messages of PtdIns $(4,5)-\mathrm{P}_{2}$ hydrolysis (IP ${ }_{3}$ and DAG) by PTH. Thus, the question of whether cell activation by PTH involves stimulation of a calcium-related signal remains a critical biologic issue.

The studies reported here have been designed to examine the action of PTH on phosphoinositide metabolism in the opossum kidney $(\mathrm{OK})$ cell line (which exhibits proximal tubular characteristics). Primary cultures of canine proximal tubules, and basolateral cell membranes (BLM) prepared from isolated

2. The product of PtdIns(4,5)- $\mathbf{P}_{2}$ hydrolysis may be inositol 1,2 (cyclic)4,5-triphosphate (3). This compound is converted to $\mathrm{IP}_{3}$ by acidic extraction procedures, and is not discussed separately from $\mathrm{IP}_{3}$ for the purposes of this paper. 
segments of the proximal tubule were also studied. The BLM of proximal tubular cells is known to contain specific PTH receptors and adenylate cyclase sensitive to PTH (13-15). The studies reported here demonstrate that PTH stimulates phosphoinositide turnover through activation of phospholipase $\mathrm{C}$, resulting in the production of DAG and $\mathrm{IP}_{3}$. The studied using the BLM in vitro indicate that this effect is closely associated with receptor binding. The stimulation of $\mathrm{IP}_{3}$ may participate in the production of an elevated $\left[\mathrm{Ca}^{2+}\right]_{\mathrm{i}}$ that follows stimulation of cultured renal tubular cells by PTH.

\section{Methods}

Sources of chemicals. Myo-[2- $\left.{ }^{3} \mathrm{H}\right]$ inositol $(1.25 \mu \mathrm{Ci} / \mathrm{ml})$ was obtained from American Radio Label (St. Louis, MO) and $\left[1-^{14} \mathrm{C}\right]$ arachidonic acid $(0.42 \mu \mathrm{Ci} / \mathrm{ml})$ was obtained from Amersham Corp., (Arlington Heights, IL). Other chemicals were the highest purity available.

\section{Experimental protocol}

The OK cell line passages (Nos. 78-83), were grown in Dulbecco's minimal essential medium containing $10 \%$ fetal calf serum in a $5 \% \mathrm{CO}_{2}$ / $95 \%$ air atmosphere at $37^{\circ} \mathrm{C}$ in $25 \mathrm{~cm}^{2}$ polystyrene flasks. At confluency, and $72 \mathrm{~h}$ before study, the growth medium was changed to an inositolfree culture medium. $24 \mathrm{~h}$ before the experiments, the media was changed to one containing myo- $\left[2-{ }^{3} \mathrm{H}\right]$ inositol $\left(3-4 \times 10^{6} \mathrm{cpm} / 3 \mathrm{ml}\right)$ or $\left[{ }^{14} \mathrm{C}\right]$ arachidonic acid $\left.9-9.5 \times 10^{4} \mathrm{cpm} / \mathrm{ml}\right)$. Preliminary experiments (data not shown), revealed that labeling of the various inositol pools was at equilibrium by $24 \mathrm{~h}$. On the day of the experiment, bPTH 1-84 at varying concentrations or its vehicle ( $0.01 \mathrm{M}$ acetic acid), were added to the culture media, and the flasks were gently shaken and returned to the incubator for variable periods.

The reactions were stopped by removing the media, adding $1 \mathrm{ml}$ of $\mathrm{H}_{2} \mathrm{O}$ at $4^{\circ} \mathrm{C}$, and immediate freezing at $-50^{\circ} \mathrm{C}$. For analysis, cells were thawed, removed from flasks with a rubber policeman, and rinsed with water. After removing appropriate samples for determination of DNA, the tissue was extracted according to Grove (22). To the tissue suspension, $2 \mathrm{ml}$ of chloroform/methanol (1:1) with $10 \mathrm{mM}$ tetrabutylammonium sulfate (TBAS) was added, then $1 \mathrm{ml}$ of $0.1 \mathrm{~N} \mathrm{HCl}$, and an additional 1 $\mathrm{ml}$ of chloroform were added. The extracts were vortexed and centrifuged. The upper phases were removed and the organic phases washed with 1 $\mathrm{ml}$ chloroform $/ 0.1 \mathrm{~N} \mathrm{HCl}(1: 1 \mathrm{vol} / \mathrm{vol})$. The aqueous phases of the washes were added to the original aqueous phases.

Chromatographic techniques. Aqueous phases of the cell extracts were added to columns containing $1.5 \mathrm{ml}$ of anion exchange resin AG 1-X8 (Bio-Rad Laboratories, Richmond, CA). The IPs were eluted as described by Berridge $(23,24)$ with $15 \mathrm{ml}$ of water followed by $9 \mathrm{ml}$ of $5 \mathrm{mM}$ tetraborate, $60 \mathrm{mM}$ sodium formate followed by $16 \mathrm{ml}$ of $0.1 \mathrm{M}$ formic acid, $0.15 \mathrm{M}$ ammonium formate followed by $10 \mathrm{ml}$ of $0.1 \mathrm{M}$ formic acid, $0.3 \mathrm{M}$ ammonium formate, followed by $10 \mathrm{ml}$ of $0.1 \mathrm{M}$ formic acid, $0.75 \mathrm{M}$ ammonium formate, and finally $10 \mathrm{ml}$ of $0.1 \mathrm{M}$ formic acid and $1 \mathrm{M}$ ammonium formate.

The lipid phases of the cell extracts were deacylated by the transacylation procedure of Clark and Dawson (25). The deacylated lipids were added to columns containing anion-exchange resins similar to those used for the aqueous phases of the extracts and eluted by $5 \mathrm{mM}$ sodium tetraborate, $0.15 \mathrm{M}$ ammonium formate (for glycerophosphoinositol [GPI]); $0.1 \mathrm{mM}$ formic acid, $0.3 \mathrm{M}$ ammonium formate (for GPI phosphate [GPIP]); and $0.1 \mathrm{M}$ formic acid, $0.75 \mathrm{M}$ ammonium formate (for $\left.G{ }^{\prime} P_{2}\right)$. Recovery of radiolabeled phospholipid from the deacylation procedure as GPIPs was $99 \%$ or greater. Overall, between 25 and $35 \%$ of the myo- $\left[2-{ }^{3} \mathrm{H}\right]$ inositol added to the culture media was incorporated into the cells. Recoveries from the extractions and chromatographic procedures were between 80 and $90 \%$, and PTH had no effect on recovery. Between 50 and $60 \%$ of the myo- $\left[2-{ }^{3} \mathrm{H}\right]$ inositol in the aqueous phases of the cell extracts eluted as free inositol.

For the determination of $\left[{ }^{14} \mathrm{C}\right] \mathrm{DAG}$, lipid phases of the cell extracts and authentic standards were spotted on activated silica gel G-25 thinlayer chromatographic plates and developed in the solvent system of hexane/ethylether/acetic acid (80:20:2). The lipids were identified by staining with iodine and scrapped from the thin-layer plate. $\left[{ }^{14} \mathrm{C}\right] \mathrm{DAG}$ in the spots was determined by liquid scintillation spectroscopy.

Determination of $\left[\mathrm{Ca}^{2+}\right]_{i}$. OK cells were removed from tissue culture flasks by a 20 -min exposure to $5 \mathrm{mM}$ EDTA at $37^{\circ} \mathrm{C}$. Cell suspensions were allowed to reequilibrate in growth media for $1 \mathrm{~h}$ in a shaking water bath at $37^{\circ} \mathrm{C}$, and $\left[\mathrm{Ca}^{2+}\right]_{i}$ was determined using the fluorescent indicator indo-1 of Grynkiewicz et al. (26) as previously described (27). The acetoxymethylester of indo-1 $(10 \mu \mathrm{M})$ was added to cell suspensions for $\mathbf{4 0}$ min. Cells were centrifuged at $200 \mathrm{~g}$ for $1 \mathrm{~min}$ and resuspended in a 10 $\mathrm{mM}$ buffer containing $127 \mathrm{mM} \mathrm{NaCl}, 3.8 \mathrm{mM} \mathrm{KCl}, 1.2 \mathrm{mM} \mathrm{KH}_{2} \mathrm{PO}_{4}$, $1.2 \mathrm{mM} \mathrm{CaCl}_{2}, 0.8 \mathrm{mM} \mathrm{MgCl}_{2}, 5 \mathrm{mM}$ glucose, and $10 \mathrm{mM}$ Hepes $(\mathrm{pH}$ 7.40). These cell suspensions were placed in a $2-\mathrm{ml}$ quartz cuvette in a spectrofluorometer (model 4800; SLM Instruments, Inc., Urbana, IL). The chamber was constantly stirred and the temperature maintained at $37^{\circ} \mathrm{C}$. Excitation was at $355 \mathrm{~nm}$ with an 8-nm slit width, and emission was monitored at $400 \mathrm{~nm}$ with an 8 - $\mathrm{nm}$ slit width and at $490 \mathrm{nM}$ using an interference filter (Corion Corp., Holiston, MA). The ratio of emitted light $400 / 490 \mathrm{~nm}$ was continuously recorded and used to calculate $\left[\mathrm{Ca}^{2+}\right]_{\mathrm{i}}$ as described by Grynkiewicz et al. (26).

Primary culture of proximal convoluted tubule cells. Proximal tubular cells (PTC) from the cortex of canine kidneys were isolated and cultured as previously described (17). The experimental protocols used for studies with PTC was the same as those described above for the OK cell line except for the differences in culture techniques.

Calcium uptake in permeabilized cells. OK and PTC were grown in 24-well culture plates to confluency in their respective growth media. Cells were permeabilized with $75 \mu \mathrm{g} / \mathrm{ml}$ saponin for $10 \mathrm{~min}$ at $37^{\circ} \mathrm{C}$. Plates were then washed with a cytoplasm-like buffer containing 100 $\mathrm{mM} \mathrm{KCl}, 20 \mathrm{mM} \mathrm{NaCl}, 5 \mathrm{mM} \mathrm{MgSO}_{4}, 0.96 \mathrm{mM} \mathrm{NaH}_{2} \mathrm{PO}_{4}, 25 \mathrm{mM}$ $\mathrm{NaHCO}_{3}$, and $1 \mathrm{mM}$ EGTA. The calcium concentration was adjusted to either $20 \mathrm{nM}$ or $3.3 \mu \mathrm{M}$. $\mathrm{Ca}^{2+}$ concentrations were determined using the method of Bers (28). Then $0.5 \mathrm{ml}$ of cytoplasmic medium containing $1 \mu \mathrm{Ci} / \mathrm{ml}{ }^{45} \mathrm{CaCl}$ and an ATP regeneration system $(5 \mathrm{mM}$ creatine phosphate, $5 \mathrm{U} / \mathrm{ml}$ creatine phosphokinase, and $1.5 \mathrm{mM} \mathrm{ATP}$ ) was added to the cells. Incubation was carried out at $37^{\circ} \mathrm{C}$, and calcium uptake was terminated by aspiration of the medium and washing with ice-cold cytoplasmic buffer $\times 2$. Then $0.5 \mathrm{ml}$ of Trypsin $(0.05 \%)$-EDTA $(0.02 \%)$ was added to the wells and incubated for $30-60 \mathrm{~min}$ at $37^{\circ} \mathrm{C} .250 \mu \mathrm{l}$ was aspirated from each well and counted for radioactivity in a liquid scintillation spectrometer.

Isolated proximal tubular segments. Proximal tubular segments were isolated from the cortex of mongrel dog kidneys as previously described (20). The isolated proximal tubular segments were suspended in a modified Krebs-Hensleit bicarbonate buffer containing $5 \mathrm{mM}$ glucose, $5 \mathrm{mM}$ alanine, and $5 \mathrm{mM}$ sodium lactate. They were gassed with $95 \% \mathrm{O}_{2} / 5 \%$ $\mathrm{CO}_{2}$. The tubules were resuspended in $50 \mathrm{ml}$ of Krebs-Ringer bicarbonate containing $7 \mathrm{mM}$ ATP and $100 \mu \mathrm{Ci}$ of myo- $\left[2-{ }^{3} \mathrm{H}\right]$ inositol for $3 \mathrm{~h}$. BLM were prepared from the tubular segments as previously described (29). BLM were suspended in a buffer containing $130 \mathrm{mM}$ sucrose, $26 \mathrm{mM}$ $\mathrm{KCl}, 5 \mathrm{mM} \mathrm{MgCl}$, and $50 \mathrm{mM}$ Tris- $\mathrm{HCl}(\mathrm{pH} \mathrm{7.5)}$. Characterization of the BLM preparation was previously reported (29), and the results of the characterization in the present studies were similar. Enrichment of $\mathrm{Na}^{+} / \mathrm{K}^{+}$ATPase activity was $8.2 \pm 1.5, n=10$, compared with the superficial cortical homogenate. Enrichment of alkaline phosphatase was $0.8 \pm 0.3, n=7$ and that of $6-\mathrm{NAD}$ hydrogenase was $1.0 \pm 0.3, n=7$. The activities of the above enzymes were used as markers of the BLM, the apical cell membrane, and the mitochondrial membrane, respectively.

Phosphorylation of BLM. Phosphorylation of BLM was carried out as previously described $(30,31)$ for proximal tubular brush border membranes. Suspensions of BLM containing 200-400 $\mu \mathrm{g}$ of protein were incubated in a water bath at $37^{\circ} \mathrm{C}$ for $1 \mathrm{~min}$. Then $4 \mathrm{vol}$ of solutions containing $1 \mathrm{mM} \mathrm{Mg}^{2+}$-ATP and 5-20 $\mu \mathrm{Ci}$ of $\left[\gamma^{32} \mathrm{P}\right]-\mathrm{ATP}, 26 \mathrm{mM} \mathrm{KCl}$, $5 \mathrm{mM} \mathrm{MgCl}_{2}, 1 \mathrm{mM}$ EDTA, and $1 \mu \mathrm{M}$ free $\mathrm{Ca}^{2+}, 50 \mathrm{mM}$ Tris- $\mathrm{HCl}$ (pH 7.6) with or without $\mathrm{PTH}$ and/or calmodulin according to the experiment, were added to the membrane suspension. This solution was hypotonic 
compared with the membrane suspension to cause swelling of vesicles in the preparation (which is $\sim 50 \%$ sheets, reference 29 ), and to increase the access of reagents to both sides of the membranes. Preliminary experiments revealed the lipid products of phosphorylation to be phosphatidic acid (PA), PtdIns 4-P, and PtdIns(4,5)- $\mathbf{P}_{\mathbf{2}}$.

The phosphorylation reaction was stopped at various times of incubation by addition of $3 \mathrm{ml}$ ice-cold chloroform/methanol (1:1 vol/ vol) containing $10 \mathrm{mM}$ TBAS. Extraction and chromatography were completed as described above.

Analysis of ${ }^{32}$ Pi phospholipids of BLM. Lipid extracts of BLM were spotted on Silica gel 60 thin-layer chromatographic plates (E. Merck, Darmstadt, Germany) and developed in two different solvent systems. The first system consisted of chloroform/methanol/15 $\mathrm{N}$ ammonium hydroxide/water (90:90:5:20, vol/vol), and it was used for separation of the polyphosphoinositides. The second system consisted of chloroform/ acetone/methanol/acetic acid/water (10:40:20:20:10, vol/vol) for PA. Phospholipids were localized by exposing to iodine vapors and spots labeled with ${ }^{32} \mathrm{Pi}$ were detected by autoradiography on Kodak X-Omat RP film. Authentic standards were used for identification of the phosphoinositides and PA. Phospholipid spots were scraped from the plates and their radioactivity counted in a Tri-Carb 460CD liquid scintillation counter (Packard Instrument Co., Inc., United Technologies, Downer's Grove, IL).

$B L M$ protein phosphorylation. BLM and $0.2-0.4 \mathrm{mg}$ protein, were suspended in $26 \mathrm{mM} \mathrm{KCl}, 130 \mathrm{mM}$ sucrose, $5 \mathrm{mM} \mathrm{MgCl}_{2}$, and $50 \mathrm{mM}$ Tris- $\mathrm{HCl}$ (pH 7.5). They were reacted with similar solutions for phosphorylation without sucrose containing $1 \mathrm{mM} \mathrm{Mg-ATP}$, and 5-20 $\mu \mathrm{C}$ of $\left[\gamma^{32} \mathrm{Pi}\right]-\mathrm{ATP}$, and where appropriate: $1 \mu \mathrm{M} \mathrm{Ca}^{2+}, 1 \mathrm{mM}$ EGTA, 3 $\times 10^{-7} \mathrm{M}$ calmodulin, $10^{-7} \mathrm{M}$ bPTH $1-84,10^{-6} \mathrm{M} 3^{\prime} 5^{\prime}$-cAMP, and 2 $\times 10^{-4} \mathrm{M} \mathrm{W13}$. Reactions were stopped by addition of an ice-cold, 60 $\mathrm{mM}$ Tris- $\mathrm{HCl}$ (pH 5.8) containing $10 \%$ sodium dodecyl sulfate (wt/vol) and $30 \%$ glycerol (wt/vol). Samples were boiled for $2 \mathrm{~min}$, cooled, and frozen at $-70^{\circ} \mathrm{C}$. BLM samples containing $100-200 \mu \mathrm{g}$ protein were added to $10 \%$ acrylamide slab gels and electrophoresis was performed for $4 \mathrm{~h}$ with $6 \mathrm{milliA} / \mathrm{gel}$. Gels were stained with Commassie Blue, dried, and exposed to radiographic film. Autoradiograms were developed after 3-7 d of exposure.

Chemical analyses. DNA content of renal tubular cells was determined by the method of Labarca and Paigen (32). $\mathrm{Na}^{+} / \mathrm{K}^{+}$ATPase, 6 NAD hydrogenase and alkaline phosphatase were measured by methods previously described (29).

Statistical analysis. The significance of differences between the results for vehicle-treated and PTH-treated cells and membranes were determined by the use of the unpaired $t$ test.

\section{Results}

Myo- $\left[2-{ }^{3} \mathrm{H}\right]$ inositol labeling of $\mathrm{OK}$ cells and separation of phosphoinositols. The OK cells were grown as described in Methods for 7-10 d to confluency. After incubation in inositol-free media and labeling with myo- $\left[2-{ }^{3} \mathrm{H}\right]$ inositol as described in Methods, the cells were exposed to PTH, cyclic nucleotides, or the respective vehicle for variable periods. After the experimental incubations, the tissues were extracted and the aqueous phases of the extracts were added to columns containing an anion-exchange resin, and eluted as described in Methods. Fig. $1 \mathrm{~A}$ shows a representative elution profile. There were six peaks of myo$\left[2{ }^{3} \mathrm{H}\right]$ inositol representing inositol (I), GPI, IP, $\mathrm{IP}_{2}$, and $\mathrm{IP}_{3}(23$, $24,33)^{3}$. These were identified by the elution pattern of pure

3. The finding that $\mathrm{IP}_{3}$ as identified in this paper is a mixture of inositol 1,3,4-triphosphate and inositol 1,4,5-triphosphate is beyond the objective of this paper (34). Ins 1,3,4, $P_{3}$ may be a breakdown product of Ins $1,3,4,5 \mathrm{P}_{4}$ formed by phosphorylation of Ins $1,4,5 \mathrm{P}_{3}(35)$. The generic term $\mathrm{IP}_{3}$ will be used to refer to the product isolated from the anionexchange columns which probably represents both Ins $1,4,5 P_{\mathbf{3}}$ and Ins $1,3,4 \mathrm{P}_{3}$.
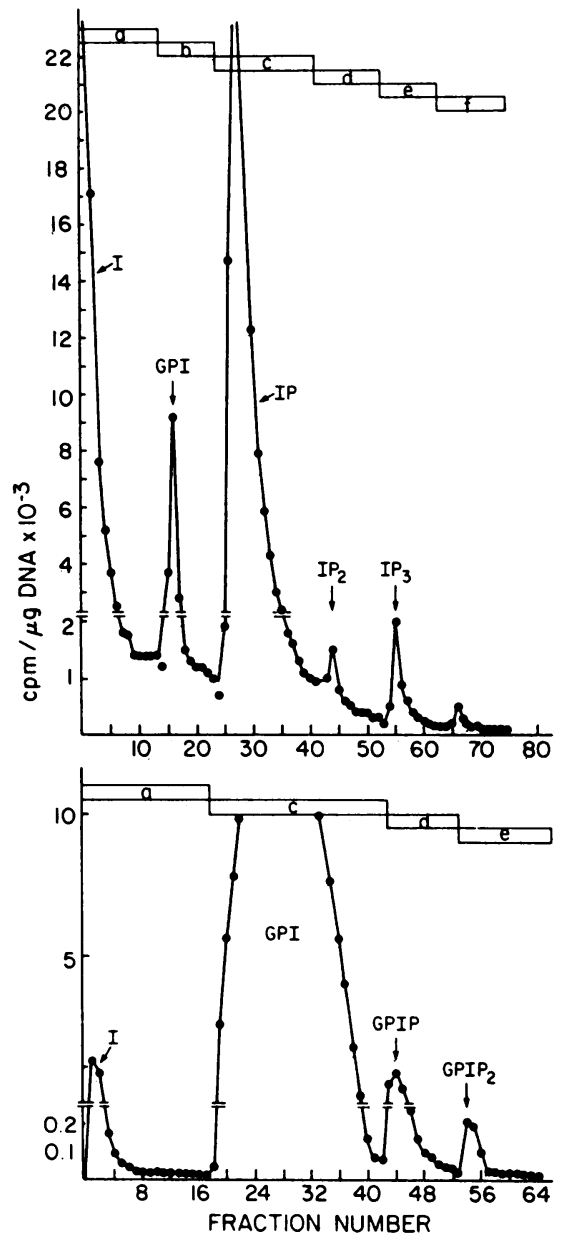

Figure 1. Anion-exchange chromatography of aqueous IPs, and deacylated phosphoinositides extracted from OK cells. Confluent cells in an inositol-free media were incubated with myo- $\left[2-{ }^{3} \mathrm{H}\right]$ inositol $(3-5$ $\times 10^{-6} \mathrm{cpm} / 3 \mathrm{ml}$ ) for $24 \mathrm{~h}$. Experiments were conducted as described in Methods. Aqueous phases of the cell extracts were applied to columns containing AG 1 X-8 formate form anion-exchange resin and eluted with: a, water for inositol; b, $5 \mathrm{mM}$ sodium tetraborate $/ 60 \mathrm{mM}$ sodium formate for GPI; c, $0.1 \mathrm{M}$ formic acid/0.15 $\mathrm{M}$ ammonium formate for IP; $\mathrm{d}, 0.1 \mathrm{M}$ formic acid/0.3 $\mathrm{M}$ ammonium formate for $\mathrm{IP}_{2}$; e, $0.1 \mathrm{M}$ formic acid/0.75 $\mathrm{M}$ ammonium formate for $\mathrm{IP}_{3}$; and $\mathrm{f}$, $0.1 \mathrm{M}$ formic acid/1 $\mathrm{M}$ ammonium formate. The lipid phases of the extract were deacylated as described in Methods and applied to similar anion-exchange columns and eluted with the deletion of solutions $b$ and $f$ and substitution of $5 \mathrm{mM}$ sodium tetraborate $/ 150 \mathrm{mM}$ sodium formate for solution c. Fractions of $1 \mathrm{ml}$ were collected and counted for ${ }^{3} \mathrm{H}$ by liquid scintillation spectroscopy.

standards. The acidic extraction procedure eliminated inositol cyclic phosphates from the elution profile (23). The small peak eluting after $\mathrm{IP}_{3}$ has not been identified as yet.

The lipid phases of the extracts were deacylated and eluted from columns containing anion-exchange resins as described in Methods. Myo- $\left[2-{ }^{3} \mathrm{H}\right]$ inositol was present in four peaks: free inositol, GPI, GPIP, and GPIP ${ }_{2}$. The latter three peaks represented the original inositol phospholipids, PtdIns, PtdIns 4-P, and PtdIns(4,5)-P $\mathrm{P}_{2}$, respectively (Fig. $1 \mathrm{~B}$ ).

Table I shows the distribution of incorporated myo-[2$\left.{ }^{3} \mathrm{H}\right]$ inositol among the various inositides. Most of the label appeared in PtdIns, whereas the levels of PtdIns 4-P and 
Table I. Incorporated Myo- $\left[2-^{3} \mathrm{H}\right]$ inositol in OK Cells

\begin{tabular}{lcc}
\hline Inositide & DNA & Distribution \\
\hline & $c p m / \mu g$ & $\%$ \\
GPI & $7,250 \pm 540$ & 4.1 \\
IP & $19,293 \pm 1,590$ & 11.0 \\
IP $_{2}$ & $500 \pm 110$ & 0.3 \\
IP $_{3}$ & $1,417 \pm 173$ & 0.8 \\
PtdIns & $145,624 \pm 2,074$ & 83 \\
PtdIns 4-P & $1,084 \pm 74$ & 0.6 \\
PtdIns(4,5)-P & $370 \pm 12$ & 0.2 \\
\hline
\end{tabular}

Data are mean $\pm \mathrm{SE}, n=4$.

PtdIns $(4,5)-\mathrm{P}_{2}$ in the cell extracts were low. The largest fraction in the aqueous phases of the cell extracts was IP, as expected from the pattern of phospholipid labeling.

Effect of PTH on $\mathrm{IP}_{3}$ release. Addition of PTH to OK cells labeled with myo-[2- $\left.{ }^{3} \mathrm{H}\right]$ inositol incubations produced a prompt and sustained increase in $\mathrm{IP}_{3}$ production (Table II). Although the levels of IP, which were the largest IP fraction, also tended to increase, this effect was smaller than the effect on $\mathrm{IP}_{3} . \mathrm{IP}_{2}$ levels were not affected by PTH. In concert with the stimulation of $\mathrm{IP}_{3}$ production, DAG levels were also increased by PTH (Fig. 2).

The effect of PTH on the levels of myo- $\left[2-{ }^{3} \mathrm{H}\right]$ inositol-containing lipids were as predicted by the effects on IP production. There was a rapid decrease in the levels of $\left[{ }^{3} \mathrm{H}\right] \operatorname{PtdIns}(4,5)-\mathrm{P}_{2}$ (Table III). Thereafter, $\left[{ }^{3} \mathrm{H}\right] \mathrm{PtdIns}(4,5)-\mathrm{P}_{2}$ levels recovered to values not different from control in $1 \mathrm{~min}$ and increased above control at $5 \mathrm{~min}$.

The effect of PTH was dose related (Table IV). Maximal effects were observed at $10^{-7} \mathrm{M}$. At $10^{-10} \mathrm{M}$ PTH, the effects on $\mathrm{IP}_{3}$ production were still detectable. The dose-dependent stimulation of $\mathrm{IP}_{3}$ production was more sensitive than the reported dose response of cAMP production in these cells (36). However, modulation of cAMP and $\mathrm{IP}_{3}$ by PTH in OK cells will have to be studied together to adequately address the questions of sensitivity and modulation of one pathway without the other. The $\mathrm{IP}_{3}$ response Table IV shows still reflected an insensitivity to PTH. The accessibility of the receptor for hormone

Table II. Effects of PTH and cAMP on $I_{3}$ and IP Production by $\mathrm{OK}$ Cells

\begin{tabular}{|c|c|c|c|}
\hline & $10 \mathrm{~s}$ & $30 \mathrm{~s}$ & $5 \mathrm{~min}$ \\
\hline & $c p m / \mu g D N A$ & $c p m / \mu g D N A$ & $c p m / \mu g D N A$ \\
\hline \multicolumn{4}{|l|}{$\mathrm{IP}_{\mathbf{3}}$} \\
\hline Control $n=7$ & $1,314 \pm 137$ & $1,417 \pm 173$ & $1,404 \pm 195$ \\
\hline PTH, $10^{-7} \mathrm{M} n=4$ & $1,717 \pm 270^{*}$ & $2,128 \pm 270^{*}$ & $2,165 \pm 292^{*}$ \\
\hline cAMP, $10^{-3} \mathrm{M} n=3$ & $1,313 \pm 281$ & $1,277 \pm 179$ & $1,685 \pm 298$ \\
\hline \multicolumn{4}{|l|}{ IP } \\
\hline Control $n=7$ & $19,950 \pm 1,000$ & $19,256 \pm 810$ & $19,256 \pm 1,300$ \\
\hline PTH, $10^{-7} \mathrm{M} n=4$ & $21,115 \pm 890$ & $20,602 \pm 1,460$ & $21,001 \pm 2,357$ \\
\hline $\mathrm{cAMP} \times 10^{-3} \mathrm{M} n=3$ & $17,900 \pm 358$ & $16,711 \pm 240$ & $17,825 \pm 900$ \\
\hline
\end{tabular}

$* P<0.05$

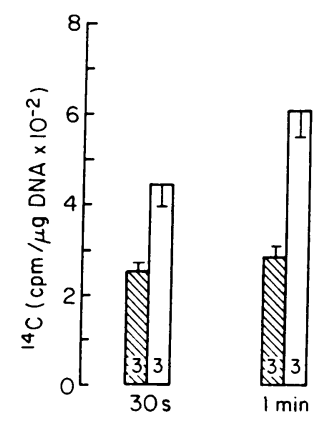

Figure 2. Effects of PTH on DAG production in OK cells. Experiments were conducted as described in Methods, and $\left[{ }^{14} \mathrm{C}\right]$ arachidonic acid was substituted for myoinositol $24 \mathrm{~h}$ before the experiment. Analysis of DAG content in the lipid extracts was performed as described in Methods. Results are mean \pm SE of three experiments, PTH $>$ control, $P<0.05$. Hatched bars, control; open bars, $10^{-7}$ M PTH.

binding, the expression of PTH receptors in OK cells, and insensitivity of the detection methods must be considered as potential and unexplored factors leading to apparent lack of sensitivity to PTH in this model system of polarized anchoragedependent cells on a solid support.

Stimulation of IP release from PTC grown in primary culture by $P T H$. As a transformed cell line, OK cells may potentially exhibit a response to PTH not found in nontransformed cells. Thus, the effects of PTH on PTC grown in primary culture were tested. PTC were grown to confluency in a defined media as previously described (17). When the experimental protocols described in Methods for the OK cells were repeated in the primary culture of PTC, there were significant differences in the incorporation of myo- $\left[2-{ }^{3} \mathrm{H}\right]$ inositol. In primary culture of PTC, incorporation of the myo- $\left[2-{ }^{3} \mathrm{H}\right]$ inositol label was $5-10 \%$ compared with the $25-35 \%$ observed in the OK cells. Despite the lower level of inositol labeling, the aqueous phases of the cell extracts of the primary culture of PTC had IP levels that were readily detectable. The predominance of PtdIns and IP shown in the OK cells was again present in the PTC. PTH produced a prompt increase in the production of the IPs by $30 \mathrm{~s}$ Table $\mathrm{V}$ shows. The largest effect was on $\mathrm{IP}_{3}$ production as in the $\mathrm{OK}$ cells.

Effects of PTH on $\left[\mathrm{Ca}^{2+}\right]_{i}$ in OK cells. If PTH indeed increases $\mathrm{IP}_{3}$ production, an effect of the hormone to transiently increase $\left[\mathrm{Ca}^{2+}\right]_{\mathrm{i}}$ would be expected. We have previously shown (17) that PTH increases $\left[\mathrm{Ca}^{2+}\right]_{i}$ in confluent PTC grown in defined media. As Fig. 3 shows, PTH also produced a prompt calcium transient in suspensions of OK cells. Basal $\left[\mathrm{Ca}^{2+}\right]_{\mathrm{i}}$ was $145 \pm 15 \mathrm{nM}, n$ $=15$. During multiple experiments similar to that shown in Fig. 5 , PTH produced an immediate $40-50 \%$ increase in $\left[\mathrm{Ca}^{2+}\right]_{\mathrm{i}}$ which returned to basal levels in the course of $\sim 1 \mathrm{~min}$.

Calcium uptake in saponin-treated $O K$ and PTC. An effect of $\mathrm{IP}_{3}$ production in other cells, has been to cause a transient release of $\mathrm{Ca}^{2+}$ from an intracellular nonmitochondrial pool

Table III. Effect of PTH on Phosphatidylinositol 4,5-bisphosphate, PtdIns(4,5)- $P_{2}$, Hydrolysis in OK Cells

\begin{tabular}{|c|c|c|c|}
\hline & \multicolumn{3}{|l|}{$\operatorname{PtdIns}(4,5)-P_{2}$} \\
\hline & $10 \mathrm{~s}$ & $30 \mathrm{~s}$ & $5 \mathrm{~min}$ \\
\hline & $c p m / \mu g D N A$ & $c p m / \mu g D N A$ & $c p m / \mu g D N A$ \\
\hline Control $n=4$ & $390 \pm 20$ & $370 \pm 21$ & $195 \pm 14$ \\
\hline PTH $n=4$ & $187 \pm 17^{*}$ & $217 \pm 22^{*}$ & $233 \pm 23$ \\
\hline
\end{tabular}

$* P<0.05$ 
Table IV. Dose-dependent Effect of PTH on $I_{3}$ Production

\begin{tabular}{lll}
\hline & & Control \\
\hline & $c p m / \mu g$ DNA & $\%$ \\
Control & $1354 \pm 117$ & - \\
bPTH 1-84 $10^{-7} \mathrm{M}$ & $2107 \pm 24^{*}$ & 155 \\
bPTH 1-84 $10^{-8} \mathrm{M}$ & $1714 \pm 112^{\ddagger}$ & 127 \\
bPTH 1-84 $10^{-9} \mathrm{M}$ & $1648 \pm 10^{\ddagger}$ & 122 \\
bPTH 1-84 $10^{-10} \mathrm{M}$ & $1600 \pm 100^{\ddagger}$ & 118 \\
\hline
\end{tabular}

Data are mean $\pm S E$ of three experiments performed in duplicate or triplicate.

$*>\mathrm{C}, P<0.01$.

${ }^{\ddagger}>\mathrm{C}, P<0.05$.

(4-6). To study the homeostasis of cellular calcium in the PTC and OK cells, the cells were grown as described in Methods and exposed to Saponin. Then the media were changed to a buffer made to resemble the cytosol as described in Methods. The uptake of ${ }^{45} \mathrm{Ca}$ was examined in the presence and absence of an uncoupler and a mitochondrial ATPase inhibitor, (carbonyl) cyanide $p$-bifluoromethoxyphenylhydrazone (FCCP), and oligomycin. At low media calcium concentrations $(0.02 \mu \mathrm{M})$, ATPstimulated calcium uptake was similar in both conditions (Fig. 4). When the media calcium was raised to $3 \mu \mathrm{M}$, ATP-stimulated calcium uptake in the FCCP and oligomycin-treated cells was similar to the calcium uptake observed at $0.02 \mu \mathrm{M}$ calcium. However, in the untreated cells there was a dramatic increase in ATP-stimulated calcium uptake. These results indicate that at low calcium concentrations, a nonmitochondrial intracellular organelle is largely responsible for ATP-stimulated calcium uptake. However, at higher calcium concentrations, the mitochondria represents a much larger potential calcium reservoir than the nonmitochondrial pool. These data are similar to those of Bonventre et al. in procine kidney-derived continuous cell line cells (37). At extracellular calcium concentrations of 0.02 $\boldsymbol{\mu}$, ATP-stimulated calcium uptake was rapidly released by adding $5.0 \mu \mathrm{M} \mathrm{IP}$. The release of calcium by $\mathrm{IP}_{3}$ was short lived and by 5-10 min ATP-stimulated calcium uptake was restored. These results demonstrate that $\mathrm{IP}_{3}$ produces a prompt release of calcium from the intracellular store accumulating calcium in the presence of ATP. Data from other investigators suggest that the nonmitochondrial store, which is responsible for this ATPdependent calcium uptake, is the endoplasmic reticulum (4-6, 38).

Effects of PTH on IP and PtdIns(4,5)- $P_{2}$ turnover in BLM.

Table V. Effect of PTH on Production of Inositol Phosphates in Primary Cultures of Canine Proximal Tubule Cells

\begin{tabular}{llll}
\hline & IP & $\mathrm{IP}_{2}$ & $\mathrm{IP}_{3}$ \\
\hline & $c p m / \mu g D N A$ & $c p m / \mu g D N A$ & $c p m / \mu g D N A$ \\
Control & $7500 \pm 400$ & $1075 \pm 100$ & $2625 \pm 250$ \\
PTH $\left(10^{-7}\right)$ & $8725 \pm 550^{*}$ & $1550 \pm 105^{*}$ & $3900 \pm 300^{*}$
\end{tabular}

Data are mean $\pm \mathrm{SE}, n=4$ at $30 \mathrm{~s}$ of incubation.

$* P<0.05$.

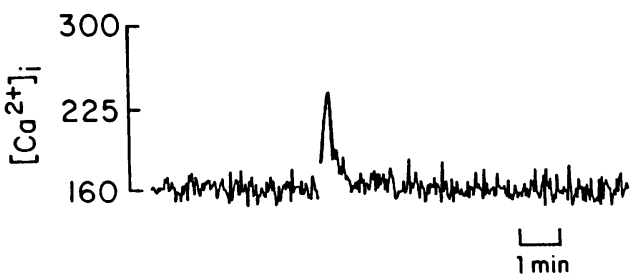

Figure 3. Effect of PTH on $\left[\mathrm{Ca}^{2+}\right]_{i}$ in OK cells. OK cells grown to confluency were suspended with indo-1 as described in Methods. The ratio of emitted light at $400 / 490 \mathrm{~nm}$ was continuously recorded. The break in the tracing represents the addition of $10^{-7} \mathrm{M}$ PTH.

Because we have previously shown that PTH produces an increase in the phosphoinositides of the brush border membrane of PTC (18), experiments were designed to analyze whether PTH could directly effect PtdIns(4,5)- $\mathrm{P}_{2}$ turnover in isolated basolateral membranes. This would indicate that the effect of PTH on $I_{3}$ release and PtdIns(4,5)- $P_{2}$ turnover was closely linked to receptor binding. To perform these experiments, isolated proximal tubular segments were prepared from the cortex of canine kidneys as described in Methods. The segments were labeled with myo- $\left[2-{ }_{-}^{3} \mathrm{H}\right]$ inositol as described in Methods. After labeling with myo- $\left[2-{ }^{3} \mathrm{H}\right]$ inositol, BLM were prepared from the proximal tubular segments. Characterization of the BLM were similar to results previously reported from this laboratory for freshly prepared BLM. Incorporation of the labeled inositol into the proximal tubular segments was only $2-5 \%$ of the label. Despite these low rates of incorporation, the levels of IPs in the aqueous phases of the extracts for BLM were detectable although the levels of IP released were much lower than that observed in the whole cell extracts of OK and PTC cultures. This is probably due to the cytoplasmic nature of a PtdIns-specific phospholipase-C (unpublished results, Suzuki, Y., and K. Hruska), whereas the

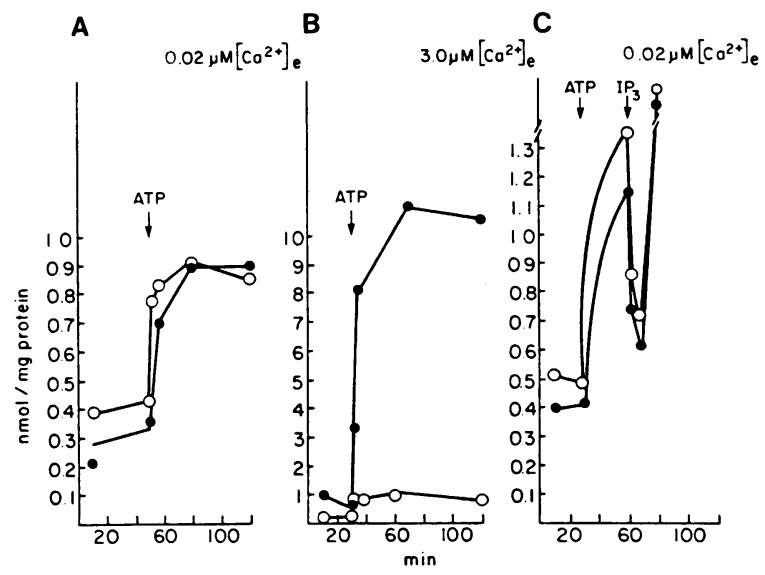

Figure 4. Effect of $\mathrm{IP}_{3}$ on ATP-stimulated calcium uptake in saponintreated OK and PTC. Suspensions of OK and PTC were treated with saponin as described in Methods. The results are shown for OK cells but they were exactly similar in PTC. $A$, calcium uptake stimulated by ATP in an extracellular calcium buffer of $0.2 \mu \mathrm{M}$. B, ATP-stimulated calcium uptake in the presence and absence of FCCP and oligomycin at 3.0 $\mu \mathrm{M}$ extracellular calcium. $C$, effects of $\mathrm{IP}_{3} 0.5 \mu \mathrm{M}$ on ATP-stimulated calcium uptake with an extracellular calcium concentration of $0.2 \mu \mathrm{M}$. Results are the mean of four experiments done in triplicate. Solid circles, control; open circles, FCCP-oligomycin. 


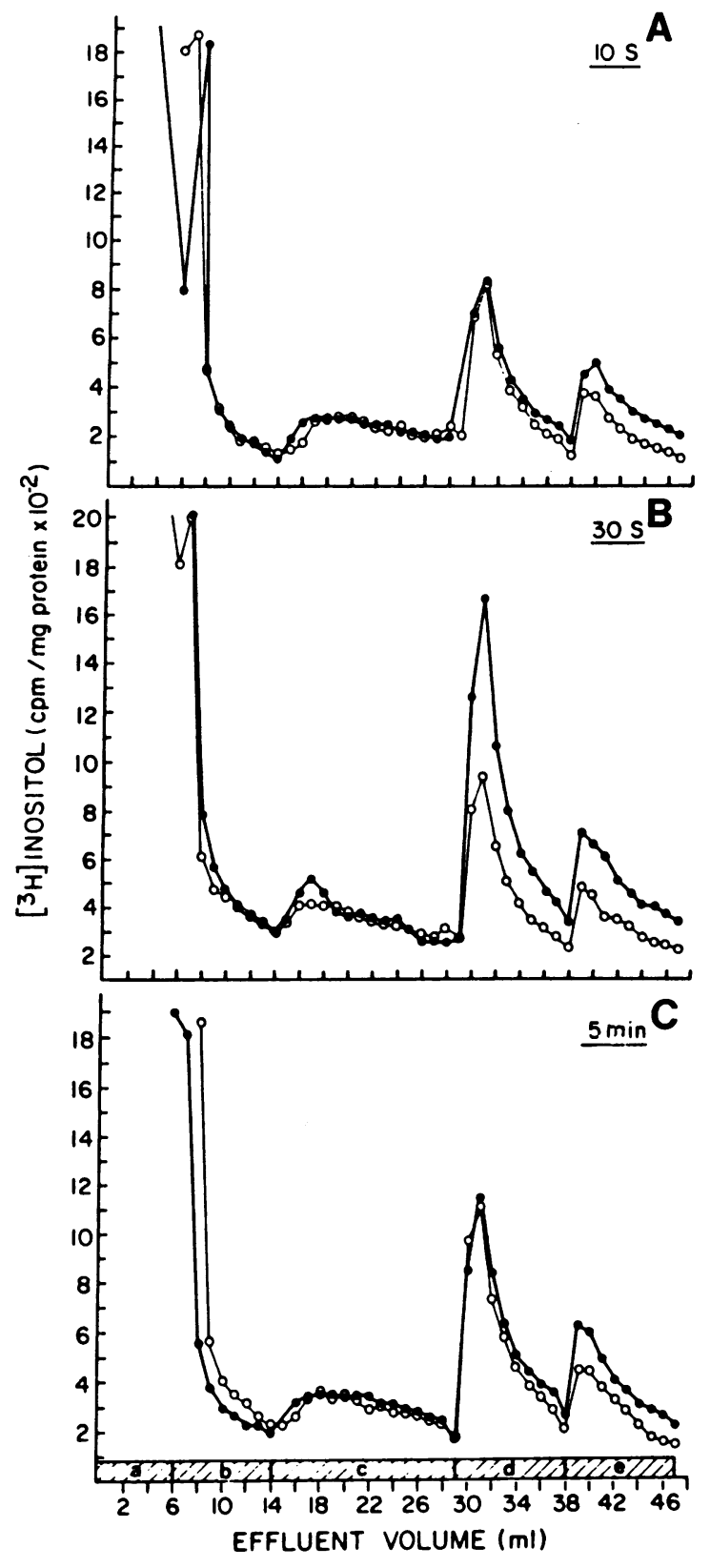

Figure 5. Effect of PTH on $\mathrm{IP}_{3}$ release from BLM. BLM were prepared from isolated proximal tubular segments labeled with myo-[2${ }^{3} \mathrm{H}$ ]inositol as described in Methods. The elution of IPs (steps $a-e, C$ ) was described in the legend to Fig. 1. Data are the mean of two experiments. $10^{-7} \mathrm{M}$ PTH produced a prompt and sustained increase in $\mathrm{IP}_{3}$ (fractions 39-43) release from the BLM. Similar results were observed in two other experiments, but with lower counts in all of the IP fractions. Solid circles, b-PTH 1-84; open circles, control.

membrane-bound phospholipase-C is specific for PtdIns $(4,5)$ $P_{2}$. As Fig. 5 shows, PTH produced a prompt and sustained increase in the production of $\mathrm{IP}_{3}$. The effect of PTH on the production of $\mathrm{IP}_{2}$ lagged behind $\mathrm{IP}_{3}$ and was transient, whereas the effect on IP was less.

To further study the effects of PTH on phosphoinositide turnover in BLM, the effects of PTH on ${ }^{32} \mathrm{Pi}$ incorporation into phospholipids from $\left[r^{32}\right.$ Pi]ATP was studied as described in
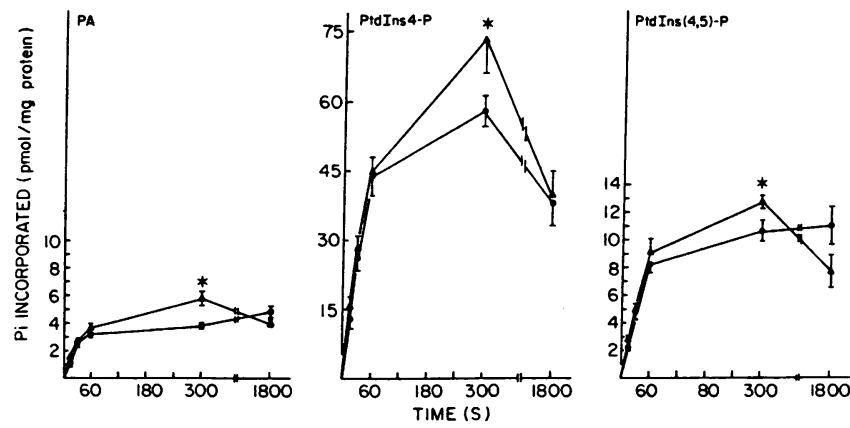

Figure 6. Effect of PTH on phospholipid phosphorylation of BLM. BLM were prepared and phosphorylated as described in Methods. The incorporation of ${ }^{32} \mathrm{Pi}$ from $\gamma^{32} \mathrm{P}$-ATP was increased in BLM treated with PTH at $5 \mathrm{~min}$. Data are shown as ${ }^{32} \mathrm{Pi}$ incorporated into phos pholipid as the mean \pm SE of five experiments. * PTH $>$ control, $P$ $<0.05$. Solid triangles, b-PTH 1-84 $10^{-6} \mathrm{M}$; solid circles, control.

Methods. As reported previously $(18,30)$, the phospholipids labeled in these experiments were PA, PtdIns 4-P, and PtdIns(4,5)$P_{2}$. PtdIns $(4,5)-P_{2}$ turnover stimulates ${ }^{32} \mathrm{Pi}$ incorporation from ATP as a result of phosphorylation of PtdIns and PtdIns 4-P (1, 2, 20, 39). Also, the product of PtdIns(4,5)- $\mathrm{P}_{2}$ turnover, DAG, is phosphorylated to PA. The enzyme DAG kinase has been shown to maintain very low DAG levels in the plasma membrane using substrate in the reaction to near completion in producing PA $(39,40)$. As Fig. 6 shows, incubation of BLM with PTH produced an increase in ${ }^{32} \mathrm{Pi}$ incorporation into PA, PtdIns 4-P, and PtdIns $(4,5)-\mathrm{P}_{2}$ at $5 \mathrm{~min}$. After $5 \mathrm{~min}$, the levels of $\left[{ }^{32} \mathrm{Pi}\right] \mathrm{PA},\left[{ }^{32} \mathrm{Pi}\right] \mathrm{PtdIns}$ 4-P, and $\left[{ }^{32} \mathrm{Pi}\right] \mathrm{Ptd} I n s(4,5) \mathrm{P}_{2}$ declined in BLM treated with PTH. By 30 min of incubation, the levels of [ $\left.{ }^{32} \mathrm{Pi}\right] \mathrm{PtdIns}(4,5)-\mathrm{P}_{2}$ were significantly lower in the PTH-treated BLM, which indicated a greater rate of $\operatorname{PtdIns}(4,5)-\mathrm{P}_{2}$ hydrolysis in PTH-treated BLM as capacity for $\left.{ }^{32} \mathrm{Pi}\right]$ phosphorylation was exhausted. These data indicate that PTH-stimulated phosphoinositide turnover in BLM resulted in an increased rate of ${ }^{32} \mathrm{Pi}$ incorporation into the polyphosphoinositides through phosphorylation of PtdIns and PtdIns 4-P. The hydrolysis of

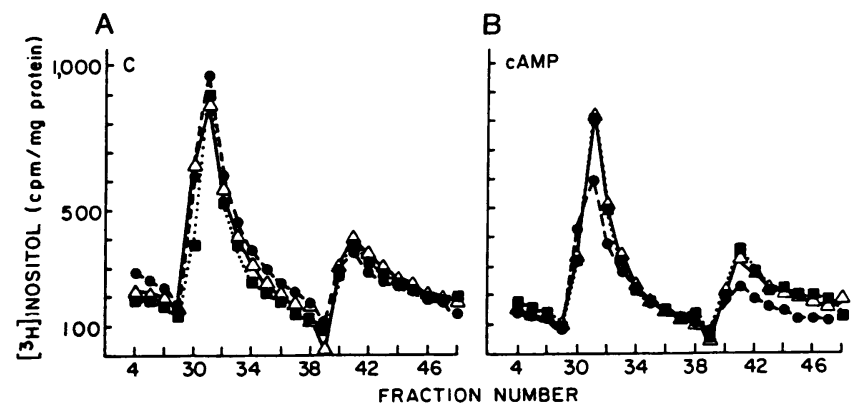

Figure 7. Effect of dibutyryl c-AMP on $\mathrm{IP}_{2}$ and $\mathrm{IP}_{3}$ production in BLM prepared from proximal tubular segments. Shown are the terminal phases of the elution from anion-exchange columns, fractions 30 38 , $\mathrm{IP}_{2}$, and $40-45, \mathrm{IP}_{3}$. Results are mean of an experiment performed in triplicate. $A$, control incubations. $B$, incubations with dibutyryl cAMP $\left(10^{-3} \mathrm{M}\right)$. At $10 \mathrm{~s}\left(10^{\prime \prime}\right) \mathrm{IP}_{2}$ and $\mathrm{IP}_{3}$ levels were decreased in the incubations of BLM with dibutyryl cAMP as compared with control. Solid circles, $10^{\prime \prime}$; open triangles, $1^{\prime}, 1^{\prime}+$; solid squares, $5^{\prime}, 5^{\prime}+$. 
PtdIns(4,5)- $\mathrm{P}_{2}$ decreased product inhibition of PtdIns kinase and the stimulation of phosphorylation resulted (41).

Effect of 3'5'-cAMP on PtdIns(4,5)-P $P_{2}$ turnover. To study the effects of cyclic nucleotides on the turnover of PtdIns(4,5)- $\mathrm{P}_{2}$ hydrolysis and $\mathrm{IP}_{3}$ release, experiments identical to those Figs. 5 and 6 show were repeated using additions of dibutyryl cAMP $10^{-3} \mathrm{M}$ instead of PTH. BLM were prepared from isolated proximal tubular segments prelabeled with myo- $\left[2{ }^{3} \mathrm{H}\right]$ inositol as described in the previous section and Methods. Fig. 7 shows production of $\mathrm{IP}_{2}$ and $\mathrm{IP}_{3}$ from labeled BLM. The results suggested that $\mathrm{IP}_{3}$ production was decreased by dibutyryl cAMP at $10 \mathrm{~s}$ of incubation but not affected at $30 \mathrm{~s}$ and $5 \mathrm{~min}$ of incubation. In addition, dibutyryl $3^{\prime} 5^{\prime}$-cAMP did not mimic the PTH effect on ${ }^{32} \mathrm{Pi}$ incorporation from [ $\left.\gamma^{32} \mathrm{Pi}\right] \mathrm{ATP}$ into PA, PtdIns 4-P, and PtdIns(4,5)-P 2 (Fig. 8).

Effect of PTH on calmodulin-dependent phosphorylation of $B L M$. To study direct stimulation of $\mathrm{Ca}^{2+}$-calmodulin-dependent functions in BLM, the effects of PTH on calmodulin-dependent protein phosphorylation was studied. As Fig. 9 shows, PTH added to BLM stimulated the phosphorylation of a protein with a molecular weight of $\sim 38,000 \mathrm{D}$. The phosphorylation of this protein was stimulated by calmodulin and inhibited by specific calmodulin inhibitors. Thus, PTH was shown to stimulate calmodulin-dependent protein kinases in the BLM in vitro. PTH addition in the absence of $\mathrm{Ca}^{2+}$-calmodulin failed to stimulate phosphorylation of the 38,000-D protein (data not shown). Although the mechanism of the PTH effect on the $\mathrm{Ca}^{2+}$-calmodulin-dependent protein kinase requires further study, these results indicate the presence of a system in the BLM dependent on $\mathrm{Ca}^{2+}$-calmodulin and responsive to PTH. Thus, the $\mathrm{Ca}^{2+}$ transient produced by PTH in PTC may affect the activity of this kinase.

\section{Discussion}

In three experimental settings, OK cells, PTC, and BLM, the data presented above demonstrate a prompt increase in $\mathrm{IP}_{3}$ production, DAG production, and PtdIns $(4,5)-\mathrm{P}_{2}$ hydrolysis after PTH addition. The high rate of incorporation of myo[2${ }^{3} \mathrm{H}$ ]inositol by $\mathrm{OK}$ cells was used to unequivocally demonstrate the stimulation of $\mathrm{IP}_{3}$ and DAG production by PTH. The studies

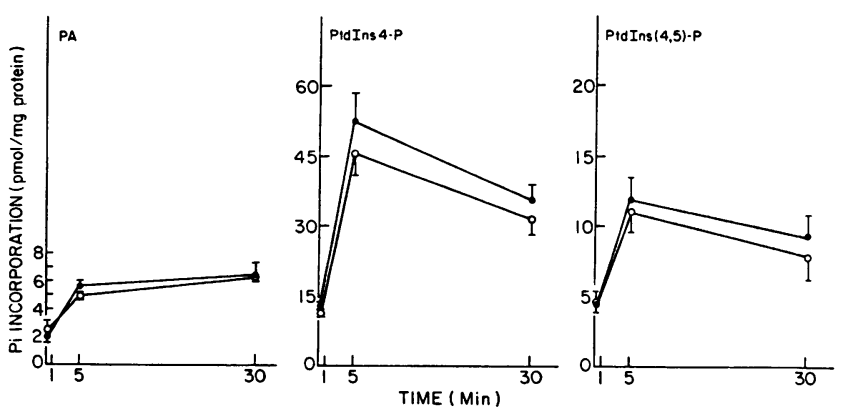

Figure 8. Effect of dibutyryl cAMP on BLM phospholipid phosphorylation. BLM were prepared and phosphorylated as described in Fig. 8 and Methods. Addition of dibutyryl cAMP $10^{-3} \mathrm{M}$ had no significant effect on ${ }^{32} \mathrm{Pi}$ incorporation of $\gamma^{32} \mathrm{P}$ ATP. Similar results were observed with additions of 8-bromo cAMP $\left(10^{-4} \mathrm{M}\right)$. Open circles, $10^{-4}$ M db-cAMP. in PTC and BLM in vitro indicate that this is an effect of PTH directly associated with receptor binding in nontransformed cells. The effects of PTH on PtdIns(4,5)- $\mathrm{P}_{2}$ hydrolysis and $\mathrm{IP}_{3}$ production were not mimicked by cAMP. In OK cells, PTH $\left(10^{-10}\right.$ M) was sufficient to stimulate production of $\mathrm{IP}_{3}$ and DAG. This dose-dependent stimulation of $\mathrm{IP}_{3}$ production compared favorably with previous reports of PTH-stimulated cAMP production in these cells (34).

In OK cells shown here, and in PTC (17), PTH produces an increase in $\left[\mathrm{Ca}^{2+}\right]_{i}$. Furthermore, in PTC and OK cells whose plasma membrane has been permeabilized by saponin, ATP produces an accumulation of calcium in a nonmitochondrial cellular pool. $\mathrm{IP}_{3}$ releases calcium rapidly and transiently from this pool. Taken together, the data presented indicate that PTHassociated receptor binding stimulates the hydrolysis of PtdIns $(4,5)-P_{2}$ producing an increase in $\mathrm{IP}_{3}$ and DAG. These substances have been shown to be important second messages for other neurotransmitters and hormones (1-10). The $\mathrm{IP}_{3}$ may participate in the production of a calcium transient that would activate calmodulin-dependent processes. The finding that PTH stimulated calmodulin-dependent protein phosphorylation supports the contention that PTH activates the calmodulin-dependent pathway of cell activation through production of a calcium transient.

To relate $\mathrm{IP}_{3}$ production and $\mathrm{PTH}$-stimulated $\mathrm{Ca}^{2+}$ transients to biologic effects in PTC, we have studied PTC membrane topography (42) and gluconeogenesis (43). In these studies, we were able to differentiate the effects of $\mathrm{Ca}^{2+}$ transients from those of increased cAMP levels. For instance, increases in $\left[\mathrm{Ca}^{2+}\right]_{i}$ produce a transient shortening and rarefaction of PTC brush border membrane microvilli, whereas cAMP produces elongation (42). The effect of PTH on brush border membrane topography is biphasic, immediate shortening and rarefaction followed by recovery and elongation after $5 \mathrm{~min}$. In contrast, agents such as angiotensin II and $\alpha_{1}$-adrenergic agents produced microvillar shortening and rarefaction with much longer recovery times. These latter agents are thought to produce cell activation through $\mathrm{IP}_{3}$-induced $\mathrm{Ca}^{2+}$ transients and $\mathrm{Ca}^{2+}$-dependent protein kinases (C-kinase and calmodulin-dependent kinase) $(1,2,4)$ and do not stimulate cAMP production. In addition, calmodulin inhibitors abolished the affects of PTH.

PTH and $\alpha_{1}$-adrenergic agonists stimulated PTC to become gluconeogenic $(43,44)$. This action of PTH and $\alpha_{1}$ agonists was mimicked by $\mathrm{Ca}^{2+}$ ionophores and prevented by buffering the increase in $\left[\mathrm{Ca}^{2+}\right]_{i}$ produced by these agents. Whereas high doses of cAMP also stimulated gluconeogenesis, PTH in the presence of an intracellular $\mathrm{Ca}^{2+}$ buffering agent was unable to stimulate gluconeogenesis despite stimulation of cAMP production. Thus, the data suggest that the $\mathrm{Ca}^{2+}$ transient produced by PTH may be sufficient to produce activation of certain metabolic processes independent of cAMP.

Activation of multiple mechanisms of cell signaling by PTH may be important in regulating the cellular response to any one signal. Rasmussen et al. have suggested that interaction of cellular messages stimulated by hormonal activation is an important feature of cell activation $(4,45)$. Modulation of one message by another affects the response to each message. In the setting of the proximal nephron, activation of adenylate cyclase and cAMP production may serve to inhibit the effect of diacylglycerol production. Diacylglycerol activation of protein kinase $\mathbf{C}$ has been shown to be the mechanism stimulating cell alkalinization 


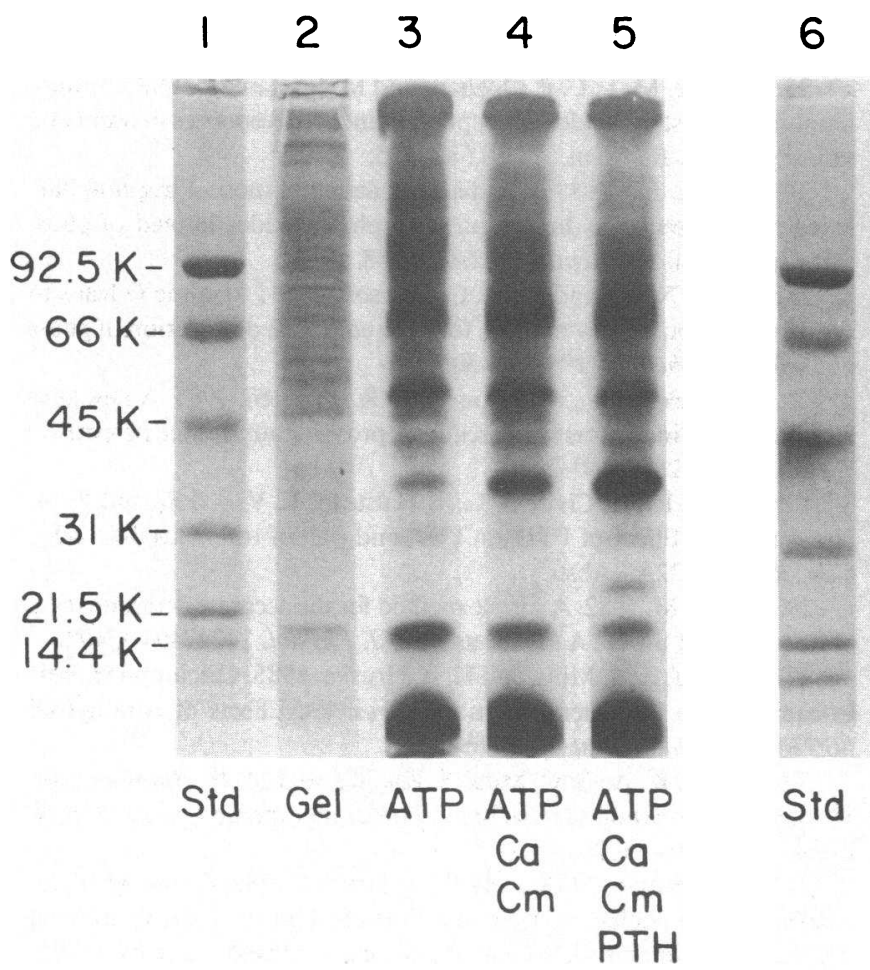

Figure 9. The effect of PTH on $\mathrm{Ca}^{2+}$-calmodulin-dependent BLM protein phosphorylation. BLM were phosphorylated as described in Methods in the presence or absence of $\mathrm{Ca}^{2+}$-calmodulin, and PTH. Audioradiograms from two separate experiments are shown (lanes 1-

through the sodium/hydrogen antiport (46). This stimulation of the sodium/hydrogen antiport producing cell alkalinization has been shown to be an important step in cell growth and hypertrophy $(47,48)$. PTH has been shown to inhibit the sodium/ hydrogen antiporter of this cell and to produce cellular acidification (49). This effect of PTH has been suggested to be regulated through cAMP-stimulated phosphorylation. Furthermore, stimulation of adenylate cyclase activity and production of cAMP participates in many of the effects of PTH on transport functions of the PTC $(31,44,49)$. However, PTH-stimulated changes in topography of the apical membrane and its effects on gluconeogenesis suggest important roles of the calcium messenger system in signal tranduction induced by PTH. Further studies will be required to fully elucidate the role of $\mathrm{IP}_{3}$ and $\operatorname{PtdIns}(4,5)-\mathrm{P}_{2}$ turnover in the control of proximal tubular function by PTH.

The mechanism whereby PTH and its receptor couple to both adenylate cyclase and phospholipase $\mathrm{C}$ also remains to be elucidated. Receptor coupling to adenylate cyclase is through the guanine nucleotide binding protein $\left(G_{s}\right.$, reference 50$)$. The -alpha subunit of $\mathrm{G}_{\mathrm{s}}$ confers the stimulatory effect, but the betagamma subunit may induce an inhibitory effect on another guanine nucleotide binding protein $\left(G_{i}\right)$. The $G_{i}$ protein stimulates the activity of phospholipase-C in some systems $(50,51)$. For PTH, if, as most of the available experimental data suggests a single class of PTH receptors exist in the BLM of renal tubular cells $(13,14)$, then signal transduction through a single receptor is responsible for activation of both adenylate cyclase and PtdIns $(4,5)-P_{2}$ phospholipase $C$. This unique mechanism of cell

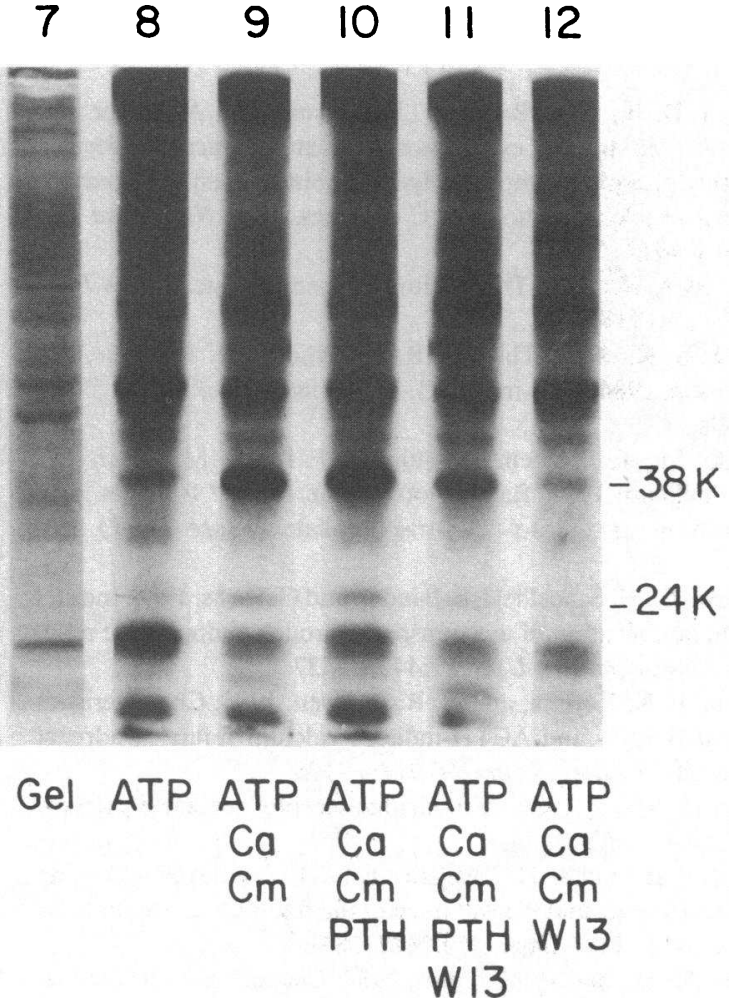

12). The additions for each lane are listed under the respective lane. W13 is a specific calmodulin antagonist. Similar results were observed in experiments using $W 7$, another calmodulin antagonist.

stimulation might occur through association of the PTH-receptor complex with both $\mathrm{G}_{\mathrm{s}}$ and $\mathrm{G}_{\mathrm{i}}$ proteins in the plasma membrane in different degrees. Increased levels of both alpha subunits of the two proteins could result in dual pathway activation. However, recent data may indicate that a low affinity receptor for PTH is present in the PTC membrane (52). If this is in fact the case, signal transduction by PTH may occur through two receptors linked to different enzymatic mechanisms. This may also relate to our previous observation that PTH increases turnover of the PtdIns cycle in the apical membrane of the PTC (18). Thus, while the present study identifies PTH stimulation of $\mathrm{IP}_{3}$ and DAG production as a mechanism of signal transduction, the mechanism of receptor coupling to phospholipase $\mathrm{C}$ and the biologic roles of these signals await further study.

\section{Acknowledgments}

We thank Allan Pollock for providing us with the OK cell line. We also thank Helen Odle for her excellent secretarial assistance.

This work was supported by a grant from the National Institutes of Health AM-09976 and AM-32087. Dr. Esbrit was a Fogerty International Fellow. Dr. Hruska was an established investigator of the American Heart Association during a portion of this work.

\section{References}

1. Berridge, M. J. 1984. Inositol triphosphate and diacylglycerol as second messengers. Biochem. J. 220:345-360. 
2. Berridge, M. J., and R. F. Irvine. 1984. Inositol trisphosphate, a novel second messenger in cellular signal transduction. Nature (Lond.). 312:315-321.

3. Wilson, D. B., T. E. Bross, W. R. Sherman, R. A. Berger, and P.W. Majerus. 1985. Inositol cyclic phosphates are produced by cleavage of phosphatidylphosphoinositols (polyphosphoinositides) with purified sheep seminal vesicle phospholipase C enzymes. Proc. Natl. Acad. Sci. USA. 82:4013-4017.

4. Rasmussen, H. 1986. The calcium messenger system. New Engl. J. Med. 314:1164-1170.

5. Joseph, S. K., A. P. Thomas, R. J. Williams, R. F. Irvine, and J. R. Williamson. 1984. Myo-inositol 1,4,5-trisphosphate. J. Biol. Chem. 259:3077-3081.

6. Prentki, M., T. J. Biden, D. Janjic, R. F. Irvine, M. J. Berridge, and C. B. Wollheim. 1984. Rapid mobilization of $\mathrm{Ca}^{2+}$ from rat insulinoma microsomes by inositol-1,4,5-trisphosphate. Nature (Lond.). 309: 562-564.

7. Muallem, S., M. Schoeffield, S. Pandol, and G. Sachs. 1985. Inositol trisphosphate modification of ion transport in rough endoplasmic reticulum. Proc. Natl. Acad. Sci. USA. 82:4433-4437.

8. Kojima, I., K. Kojima, and H. Rasmussen. 1985. Characteristics of angiotensin II-, $\mathrm{K}^{+}$- and $\mathrm{ACTH}$-induced calcium influx in adrenal glomerulosa cells. J. Biol. Chem. 260:9171-9176.

9. Putney, J. W., Jr. 1986. A model for receptor-regulated calcium entry. Cell Calcium. 7:1-12.

10. Albert, P. R., and A. H. Tashjian, Jr. 1984. Thyrotropin-releasing hormone-induced spike and plateau in cytosolic free $\mathrm{Ca}^{2+}$ concentrations in pituitary cells. J. Biol. Chem. 259:5827-5832.

11. Bates, M. D., and P. M. Conn. 1984. Calcium mobilization in the pituitary gonadotrope: relative roles of intra- and extracellular sources. Endocrinology. 115:1380-1385.

12. Michell, R. H. 1975. Inositol phospholipids and cell surface receptor functions. Biochim. Biophys. Acta. 415:81-147.

13. Bellorin-Font, E., and K. J. Martin. 1981. Regulation of the PTH-receptor-cyclase system of canine kidney: effects of calcium, magnesium, and guanine nucleotides. Am. J. Physiol. 241:F364-F373.

14. Nissenson, R. A., and C. D. Arnaud. 1979. Properties of the parathyroid hormone receptor-adenylate cyclase system in chicken renal plasma membranes. J. Biol. Chem. 254:1469-1475.

15. Segre, G. V., M. Rosenblatt, B. L. Reiner, J. E. Mahaffey, and J. T. Potts, Jr. 1979. Characterization of parathyroid hormone receptors in canine renal cortical plasma membranes using a radioiodinated sulfurfree hormone analogue. J. Biol, Chem. 254:6980-6986.

16. Chase, L. R., and G. D. Aurbach. 1967. Parathyroid function and the renal excretion of $3{ }^{\prime} 5^{\prime}$ adenylic acid. Proc. Natl. Acad. Sci. USA. 58:518-525.

17. Hruska, K. A., M. Goligorsky, J. Scoble, M. Tsutsumi, S. Westbrook, and D. Moskowitz. 1986. Effects of parathyroid hormone on cytosolic calcium in renal proximal tubular primary cultures. Am. J. Physiol. 251:F188-F198.

18. Khalifa, S., S. Mills, and K. A. Hruska. 1983. Stimulation of calcium uptake by parathyroid hormone in renal brush-border membrane vesicles. J. Biol. Chem. 258:14400-14406.

19. Bidot-Lopez, P., R. V. Farese, and M. A. Sabir. 1981. Parathyroid hormone and adenosine- $3^{\prime}, 5^{\prime}$-monophosphate acutely increases phospholipids of the phosphatidate-polyphosphoinositide pathway in rabbit kidney cortex tubules in vitro by a cycloheximide-sensitive process. Endocrinology. 108:2078-2081.

20. Meltzer, V., S. Weinreb, E. Bellorin-Font, and K. A. Hruska. Parathyroid hormone stimulation of renal phosphoinositide metabolism is a cyclic nucleotide-independent effect. 1982. Biochim. Biophys. Acta. 712:258-267.

21. Lo, H., D. C. Lehotay, D. Katz, and G. S. Levey. 1976. Parathyroid hormone-mediated incorporation of ${ }^{32} \mathrm{P}$-orthophosphate into phosphatidic acid and phosphatidylinositol in renal cortical slices. Endocr. Res. Commun. 3(Suppl. 6):377-385.

22. Grove, R. I., D. Fitzpatrick, and S. D. Schimmel. 1981. Effect of $\mathrm{Ca}^{++}$on triphosphoinositide extraction in fusing myoblasts. Lipids. 16:691-693.

23. Berridge, M. J., C. P. Downes, and M. R. Hanley. 1982. Lithium amplifies agonist-dependent phosphatidylinositol responses in brain and salivary glands. Biochem. J. 206:587-595.

24. Berridge, J. J. 1983. Rapid accumulation of inositol trisphosphate reveals that agonists hydrolyse polyphosphoinositides instead of phosphatidylinositol. Biochem. J. 212:849-858.

25. Clarke, N. G., and R. M. C. Dawson. 1981. Alkaline O leads to $\mathrm{N}$-transacylation. A new method for the quantative deacylation of phospholipids. Biochem. J. 195:301-306.

26. Grynkiewicz, G., M. Poenie, and R. Y. Tsien. 1985. A new generation of $\mathrm{Ca}^{2+}$ indicators with greatly improved fluorescence properties. J. Biol. Chem. 260:3440-3450.

27. Reid, I. R., R. Civitelli, L. R. Halstead, L. V. Avioli, and K. A. Hruska. 1986. Effect of PTH on $\mathrm{Ca}^{2+}$ and $\mathrm{pH}_{\mathrm{i}}$ of osteoblast-like cells. Clin. Res. 34:432A. (Abstr.)

28. Bers, D. M. 1982. A simple method for the accurate determination of free [Ca] in Ca-EGTA solutions. Am. J. Physiol. 242:C404-C408.

29. Scoble, J. E., S. Mills, and K. A. Hruska. 1985. Calcium transport in canine renal basolateral membrane vesicles: Effects of parathyroid hormone. J. Clin. Invest. 75:1096-1105.

30. Hruska, K. A., S. C. Mills, S. Khalifa, and M. R. Hammerman. 1983. Phosphorylation of renal brush-border membrane vesicles. J. Biol. Chem. 258:2501-2507.

31. Hammerman, M. R., and K. A. Hruska. 1982. Cyclic AMP dependent protein phosphorylation in canine renal brush border membrane vesicles is associated with decreased phosphate transport. J. Biol. Chem. 257:992-999.

32. Labarca, C., and K. Paigen. 1980. A simple, rapid, and sensitive DNA assay procedure. Anal. Biochem. 102:344-352.

33. Shayman, J. A., and A. R. Morrison. Bradykinin-induced changes in phosphatidyl inositol turnover in cultured rabbit papillary collecting tubule cells. J. Clin. Invest. 76:978-984.

34. Irvine, R. F., A. J. Letcher, D. J. Lander, and C. P. Downes. 1984. Inositol trisphosphates in carbachol-stimulated rat parotid glands. Biochem. J. 223:237-243.

35. Irvine, R. F., A. J. Letcher, J. P. Heslop, and M. J. Berridge. 1986. The inositol tris tetrakisphosphate pathway-demonstration of Ins $(1,4,5) \mathrm{P}_{3}$ 3-kinase activity in animal tissues. Nature (Lond.). 320:631634.

36. Teitelbaum, A. P., and G. J. Strewler. 1984. PTH receptors coupled to cyclic adenosine monophosphate formation in an established renal cell line. Endocrinology. 114:980-985.

37. Bonventre, J. V., and J. Y. Cheung. 1986. Cytosolic free calcium concentration in cultured renal epithelial cells. Am. J. Physiol. 250:F329F338.

38. Somlyo, A. P. 1984. Cellular site of calcium regulation. Nature (Lond.). 309:516-517.

39. Fain, J. N., S.-H. Lin, I. Litosch, and M. Wallace. 1985. Relationship between vasopressin activation of rat hepatocyte glycogen phosphorylase, inhibition of $\mathrm{Ca}^{2+}-\mathrm{Mg}^{2+}-\mathrm{ATPase}$ and phosphoinositide breakdown. In Inositol and Phosphoinositides. J. E. Bleasdale, J. Eichberg, and G. Hauser, editors. Humana Press, Clifton, NJ. 255-274.

40. Nishizuka, Y., Y. Takai, A. Kishimoto, U. Kikkawa, and K. Kaibuchi. 1984. Phospholipid turnover in hormone action. Recent Prog. Horm. Res. 40:301-345.

41. Palmer, F. B. St. C., and S. E. Mack. 1985. Hydrolysis of phosphatidylinositol 4-phosphate and phosphatidylinositol(4,5)-bisphosphate by specific phosphomonoesterases in human erythrocytes. In Inositol and Phosphoinositides. J. E. Bleasdale, J. Eichberg, and G. Hauser, editors. Humana Press, Clifton, NJ. 199-212.

42. Goligorsky, M. S., D. N. Menton, and K. A. Hruska. 1986. Parathyroid hormone-induced changes of the brush border topography and cytoskeleton in cultured renal proximal tubular cells. J. Membr. Biol. 92:151-162. 
43. Goligorsky, M. S., K. A. Hruska, and I. Karl. 1986. Hormonal control of gluconeogenesis in primary cultures of renal proximal tubular cells: role of calcium. Clin. Res. 24:596A. (Abstr.)

44. Klahr, S., and K. A. Hruska. 1983. Effects of parathyroid hormone on the renal reabsorption of phosphorus and divalent cations. In Advances in Bone and Mineral Research. W. A. Peck, editor. Elsevier/North Holland, Amsterdam. 65-124.

45. Rasmussen, H., and D. B. P. Goodman. 1977. Relationships between calcium and cyclic nucleotides in cell activation. Physiol. Rev. 57:421-509.

46. May, W. S., E. G. Lapetina, and P. Cuatrecasas. 1986. Intracellular activation of protein kinase $\mathrm{C}$ and regulation of the surface transferrin receptor by diacylglycerol is a spontaneously reversible process that is associated with rapid formation of phosphatidic acid. Proc. Natl. Acad. Sci. USA. 83:1281-1284.

47. Allemain, G. L., A. Franchi, E. Cragoe, Jr., and J. Pouyssegur. 1984. Blockade of the $\mathrm{Na}^{+} / \mathrm{H}^{+}$antiport abolishes growth factor-induced DNA synthesis in fibroblasts. J. Biol. Chem. 259:4313-4319.
48. Allemain, G. L., S. Paris, and J. Pouyssegur. 1984. Growth factor action and intracellular pH regulation in fibroblasts. J. Biol. Chem. 259: 5809-5815.

49. Pollock, A. S., D. G. Warnock, and G. J. Strewler. 1986. Parathyroid hormone inhibition of $\mathrm{Na}^{+}-\mathrm{H}^{+}$antiporter activity in a cultured renal cell line. Am. J. Physiol. 250:F217-F225.

50. Litosch, I., and J. N. Fain. 1986. Minireview: regulation of phosphoinositide breakdown by guanine nucleotides. Life Sci. 39:187-194.

51. Blackmore, P. R., S. B. Bocckino, L. E. Waynick, and J. H. Exton. 1985. Role of a guanine nucleotide-binding regulatory protein in the hydrolysis of hepatocyte phosphatidylinositol 4,5-bisphosphate by calcium-mobilizing hormones and the control of cell calcium. J. Biol. Chem. 260:14477-14483.

52. Rouleau, M. F., J. Mitchell, A. Tenenhouse, and D. Goltzman. 1986. In vivo and in vitro demonstration of parathyroid hormone receptor down-regulation in vitamin D deficient rat. J. Bone \& Min. Res. 1(Suppl. 1):322. (Abstr.) 